\title{
Prolapse of the urethral mucosa in a prepubertal Indian girl
}

\section{Sabita Pulavarthi*, Sharmila Vijayan}

Department of Obstetrics and Gynecology, Indira Gandhi Medical College and Research Institute, Puducherry, Tamil Nadu India

Received: 25 May 2018

Accepted: 26 June 2018

\section{*Correspondence:}

Dr. Sabita Pulavarthi,

E-mail: sabita.kutty@gmail.com

Copyright: () the author(s), publisher and licensee Medip Academy. This is an open-access article distributed under the terms of the Creative Commons Attribution Non-Commercial License, which permits unrestricted non-commercial use, distribution, and reproduction in any medium, provided the original work is properly cited.

\begin{abstract}
Prolapse of urethral mucosa in prepubescent girls is an uncommon entity and most often seen among native Africans. Management of these cases is controversial. Some would adopt initial medical treatment and others prefer surgical treatment as primary modality with a very few recurrences. Though urethral mucosal prolapse has been managed successfully with surgery in many African girls, the role of medical management and its success cannot be overlooked. Authors present a case of urethral mucosal prolapse in a prepubescent Indian girl who was successfully treated with medical management with no recurrence on follow up.
\end{abstract}

Keywords: Medical treatment, Prepubertal girl, Urethral mucosa prolapse

\section{INTRODUCTION}

Urethral prolapse is a protrusion of the distal urethral mucosa through the external urethral meatus and it was first described by Solingen in $1732 .^{1}$ It is a benign condition and most commonly affects girls in the age between 5-9 years. ${ }^{1,2}$

It is seen primarily among African girls but has also been reported from other races. ${ }^{3-6}$ The cause for urethral prolapse is still not known. It could be the result of poor development or atrophic changes in the collagen and elastic tissue of the urethral mucosa. ${ }^{7}$ Inadequate periurethral supporting tissue or weakness of submucosal tissue added with raised intraabdominal pressure in conditions like obesity, chronic cough and perineal trauma can act as precipitating factors. Treatment is controversial and can be conservative or surgical management. Authors report a case of urethral mucosal prolapse in an Indian girl managed successfully with medical treatment. To our knowledge this is the first case report from India.

\section{CASE REPORT}

An eight year old girl presented to the Paediatric outpatient department with history of bleeding from the external genitalia which was noticed by her mother as blood stains on her pants. She also had history of dysuria and increased frequency of micturition for the past5 days. Patient was referred to the Department of Obstetrics and gynecology with provisional diagnosis of urinary tract infection and/ or sexual abuse. History was not suggestive of any possibility of sexual abuse. She was feeling uncomfortable due to burning sensation in the genital region. On examination, the girl was thin built and there was no pallor. Examination of external genitalia revealed no active bleeding from introitus and perineum appeared normal. Gentle separation of the labia revealed a $2 * 2 \mathrm{~cm}$ reddish mass, but we could not proceed further with examination as the girl was highly uncooperative due to pain. A provisional diagnosis of interlabial mass probably vaginal tumor was made and authors planned for examination under anesthesia. Pelvic ultrasound and laboratory investigations were normal. 
Examination under anesthesia revealed a normal introitus and vagina mucosa. There was a well circumscribed, erythematous, doughnut shaped mass at the urethral meatus. An infant feeding tube was passed through the center of mass which drained clearurine, confirming that the mass was the prolapsed erythematous urethral mucosa. She was diagnosed to have urethral mucosal prolapse. Her mother was informed regarding diagnosis and its rarity among Indian population. She was counseled regarding the available management modalities and she consented to try medical management as an initial treatment. The girl was prescribed antiinflammatory drugs along with Sitzbath for three days followed by daily local application of estrogen cream. The girl was followed up after 7 days and she was comfortable with no complaints. Local examination revealed that the prolapsed urethral mucosa had reduced considerably (Figure 1). The girl was followed up regularly and no recurrence was noticed during a period of follow up for 3 years.

Figure 1: After treatment. Resolving Prolapsed urethral mucosa seen in posterior half of the urethra.

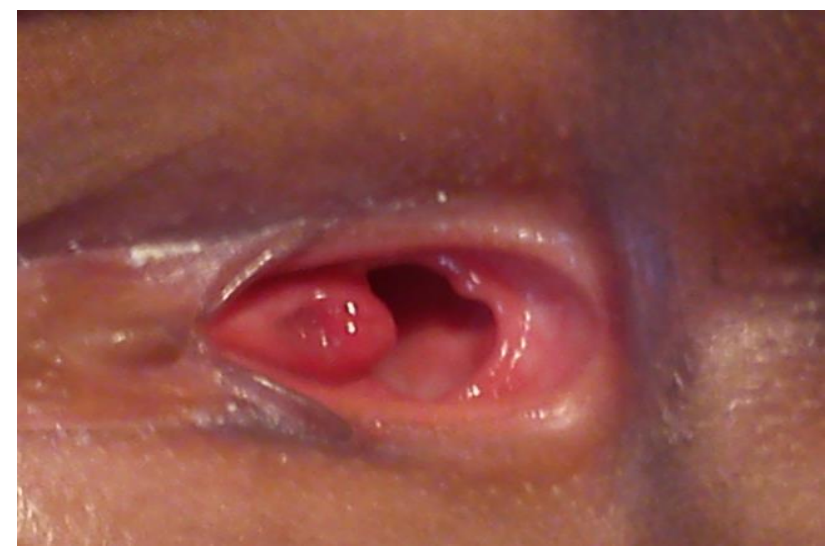

\section{DISCUSSION}

Urethral prolapse is a clinical condition where the distal urethral mucosa evaginates beyond the external urethral meatus resulting in minimal segmental prolapse with no inflammation to necrosis or ulceration.

It is more common among prepubertal girls under 10 years of age with an average age range between 4 and 7 years. It has been reported in infants as early as 6 weeks old. ${ }^{2,8,9}$

The exact etiology of condition is still not unknown. Many of them are case reports or case series and based on the findings from these reports several theories have been postulated. A hypo oestrogenic state has been suggested as an etiological factor due to its preponderance among prepubertal girls and postmenopausal women. ${ }^{10}$ Poor attachment between the two layers of smooth muscle surrounding the urethra, combined with episodic increase in intra-abdominal pressure as in constipation and chronic cough and high resting intra abdominal pressure as in obesity 3 may predispose to urethral mucosal prolapse. . $^{3,11}$ Race and socioeconomic status may play a role due to its preponderance among Africans and girls from lower socioeconomic status. ${ }^{12}$

Certain cultural practices like female genital mutilation may be a predisposing factor in the development of urethral prolapse. Adesiyun et al postulated that damage and/or disruption to the perinealmuscular attachment of the urethra could be a possible explanation for urethral mucosa prolapse following female genital mutilation ${ }^{13}$

Studied patient is a prepubescent girl of Asian race who was from a low socioeconomic status and her Body mass index was low. Poor perineal support due to poor nutrition could be the possible cause for urethral mucosal prolapse in present case.

Symptoms of urethral prolapse vary, but the common features are vaginal bleeding causing spotting on the underwear or diapers and a periurethral mass. Dysuria or perineal discomfort may be present. All the symptoms can readily be ascribed to sexual abuse and this may cause anxiety to the parents and the treating physician until sexual abuse is ruled out and diagnosis is confirmed. The diagnosis is usually made by local examination and/ or examination under anesthesia. Studied patient had all the presenting symptoms and was referred from Pediatric outpatient department to rule out sexual abuse. Differential diagnosis to this entity are caruncle, prolapsing urethrocele, condylomata, urethral papilloma, polyp, vaginal rhabdomyosarcoma, imperforate hymen and sexual abuse..$^{3,14}$

Management is the point of debate in urethral prolapse among young children due to lack of knowledge on the nature or etiology of the disease and the percentage of cases which will resolve spontaneously.

Treatment modalities range from conservative management to various operative interventions. Conservative management consists of sitz bath, local application of estrogen cream and oral antibiotics. ${ }^{1,12,15,16}$ Operative approaches includes ligation over a Foley catheter and total excision of the prolapse (Fernandes et al, Sanfilippo and Wakim). ${ }^{17,18}$ Though many modalities are available, none emerged as definitive procedure. Every modality has its meritsand demerits and hence the treatment still remains controversial.

Effectiveness of conservative treatment is limited, and recurrence rate is high. ${ }^{6,12,15,19}$ Although surgery can offer definitive treatment, it may not be the first choice due to complications that include meatal stenosis and dysuria. ${ }^{6,12}$ However, the recurrence rate is lower than with conservative management. ${ }^{20}$ Richardson 1 suggested that conservative treatment can be followed by surgical management in case of no response or recurrence. Ballohey et al proposed that surgery remains the primary 
strategy for patients with significant symptoms including pain and dysuria. ${ }^{21}$ Surgical resection is a safe modality with low recurrence rate. Recent literature advocates conservative treatment strategy and current evidence supports the use of $0.5 \%$ estrogen cream twice daily for 4-6 weeks in combination with sitzbaths as first-line therapy. In present case, though the child presented with symptoms, her mother opted for initial conservative treatment. Authors team had a felt opinion that surgical option should be reserved only for cases who do not respond to conservative therapy and in case of recurrence. The girl was followed up on regular basis and no recurrence was noted for three years following the conservative treatment.

\section{CONCLUSION}

Though, cases of urethral mucosal prolapse treated with conservative treatment modality might not respond to therapy and could have high recurrence, it can still be started as initial treatment in selected cases based on clinical symptoms.

Funding: No funding sources

Conflict of interest: None declared

Ethical approval: Not required

\section{REFERENCES}

1. Richardson DA, Hajj SN, Herbst AL. Medical treatment of urethral prolapse in children. Obstet Gynecol. 1982;59(1):69-74.

2. Fiogbe MA, Hounnou GM, Koura A, AgossouVoyeme KA. Urethral mucosal prolapse in young girls: a report of nine cases in Cotonou. African J Paediatr Surg. 2011;8(1):12-4.

3. Valerie E, Gilchrist BF, Frischer J, Scriven R, Kolz DH, Ramensfsky ML. Diagnosis and treatment of urethral prolapse in children. Urol. 1999;54(6):108284.

4. Carlson NJ, Mercer LJ, Hajj SN. Urethral prolapse in the premenarcheal female. Int J Gynecol Obstetr. 1987;25(1):69-71.

5. Fernandes ET, Dekermacher S, Sabadin MA, Vaz F. Urethral prolapsed in children. Urol. 1993;41:240-2.

6. Rudin JE, Geldt VG, Alecseev EB. Prolapse of urethral mucosa in white female children: experience with 58 cases. J Pediatr Surg. 1997;32(3):423-5.

7. Rock JA, Horowitz JR. Surgical conditions of vagina and urethra. In: Rock JA, Thompson JD, eds. T
Elinde's Operative gynecology. Philadelphia: Lippincott-Raven (publishers), 1999:911-38.

8. Akani CI, Pepple DK, Ugboma HA. Urethral prolapse: a retrospective analysis of hospitalized cases in Port Harcourt. Nigerian $\mathrm{J}$ Medicine. 2005;14(4):396-9.

9. Pouya M, Van PC, Wese FX, Opsomer RJ, Saleh M. Mucous prolapse of the urethra. Acta Urologica Belgica. 1995;63(4):23-9.

10. Batra SC, Iosif CS. Female urethra: a target for estrogen action. J Urol. 1983;129(2):418-20.

11. Lowe FC, Hill GS, Jeffs RD, Brendler CB. Urethral prolapse in children: insights into etiology and management. J Urol. 1986;135(1):100-3.

12. Trotman MD, Brewster EM. Prolapse of the urethral mucosa in prepubertal West Indian girls. Br J Urol. 1993;72(4):503-5.

13. Adesiyun AG, Samaila MO. Childhood urethral mucosa prolapse: outcome of surgical treatment. Nigerian J Surg Res. 2006;8(1):63-6.

14. Shurtleff BT, Barone JG. Urethral prolapse: Four quadrant excisional technique. J Paed Adolescent Gynaecology. 2002;15(4):207-11.

15. Venugopal S, Duncan ND, Carpenter R. Urethral prolapse in girls. Pediatric Sur Int. 1995;10(2-3):1157.

16. Redman JF. Conservative management of urethral prolapse in female children. Urol. 1982;19(5):505-6.

17. Fernandes ET, Dekermacher S, Sabadin MA, Vaz F. Urethral prolapse in children. Urol. 1993;41(3):2402.

18. Sanfilippo JS, Wakim NG. Bleeding and vulvovaginitis in the pediatric age group. Clin Obstet Gynecol. 1987;30(3):653-61.

19. Holbrook C, Misra D. Surgical management of urethral prolapse in girls: 13 years' experience. $\mathrm{Br} \mathbf{J}$ Urol Int. 2012;110(1):132-4.

20. Hillyer S, Mooppan U, Kim H, Gulmi F. Diagnosis and treatment of urethral prolapse in children: experience with 34 cases. Urol. 2009;73(5):1008-11.

21. Ballouhey Q, Galinier P, Gryn A, Grimaudo A, Pienkowski C, Fourcade L. Benefits of primary surgical resection for symptomatic urethral prolapse in children. J Pediatr Urol. 2014;10(1):94-7.

Cite this article as: Pulavarthi S, Vijayan S.

Prolapse of the urethral mucosa in a prepubertal Indian girl. Int J Reprod Contracept Obstet Gynecol 2018;7:3397-9. 